\title{
A Model of Hormonal and Environmental Involvement in Growth and Sex Differentiation in European Eel (Anguilla anguilla)
}

\author{
Gad Degani \\ Galilee Technological Center, School of Science and Technology, Tel-Hai Academic College, Upper \\ Galilee, Israel \\ Email: gad@migal.org.il
}

Received 1 August 2016; accepted 23 August 2016; published 26 August 2016

Copyright (C) 2016 by author and Scientific Research Publishing Inc.

This work is licensed under the Creative Commons Attribution International License (CC BY).

http://creativecommons.org/licenses/by/4.0/

(c) (i) Open Access

\begin{abstract}
Growth in vertebrates is a complex interaction involving the development of cells, tissues and organs. Hormones regulating growth during maturation are involved mainly in the interaction between the somatic axis and the reproduction of brain-pituitary axes. Based on the results of hormone and gene transcriptions, the secretion and treatment controlling both the somatic axis and the gonadotropic axis were affected, directly or indirectly, by the environment parameter through hormones that were studied in my laboratory. A model was proposed for sex differentiation and gonadal development correlating to the growth of European eel (Anguilla anguilla). A high growth variation is affected by the environment. At a low density of eels, the gonadotropin-releasing hormone (GnRH) affected the secretion follicle stimulation hormone (FSH) in the pituitary, steroidogenesis and aromatase (CYP19) synthesis, and the 17 $\beta$-estradiol (E2) from 11-ketotestosterone (Kt-11) causing ovary development. The ovary secretion E2 affecting the adenylate cyclase-activating polypeptide (PACAP), growth hormone (GH) and the insulin-like growth factor (IGF) stimulated rapid growth in females. On the other hand, a high density of eels caused the pituitary gland to secrete FSH at a lower level, and CYP19 was not synthesized in the gonads. The secretion of Kt-11 affected differentiation to testis, which inhibits the somatic axis in reducing growth rate.
\end{abstract}

\section{Keywords}

Hormones, Environmental, Sex Differentiation Anguilla anguilla 


\section{Introduction}

European eel (Anguilla anguilla) is a teleost species having a complex lifecycle both in sea and freshwater environments [1]. High variation in growth was discovered in European eel grown under aquacultural conditions [2], [3]. Under natural conditions, many biological aspects of European eel were studied, including lifecycle, spawning behavior, migration, growth and metamorphosis from larvae to mature. The sex ratio in silver eels varies considerably between localities, ranging between $0 \%$ to $100 \%$ for females [1], adults [4]-[8]. The lifecycle, evolution and reproduction of European eel were reviewed in detail [9]. Many aspects of eel growth and nutrition were described under artificial conditions, which have been reviewed and summarized [10] (Figure 1).

Significant differences between growth rate and size have been observed between the two sexes, with females growing faster and larger than males [11]. The environment has been found to affect growth and sex determination in eels; the females continue to grow, while the males cease to do so. Some males weigh between 15 - $200 \mathrm{~g}$. Many theoretical and applied aspects of European eel, including hormone involvement in growth and reproduction, have been investigated [10]. The administration of various hormones in eel diets influences growth [12]-[14]. In European eel, molecular cloning of the PACAP precursor has been previously shown in fish, PACAP and GH-releasing hormone (GHRH) originating from the same precursor. The effects of PACAP and GHRH on GH secretion from eel pituitary cells in primary culture have been described [15]. The growth hormone sequence analysis and transcription of European eel were studied [11], as well as gonadotropins, follicle-stimulating hormone (FSH) and luteinizing hormone (LH) [11]. Japanese eel (Anguilla japonica) (Kazeto et al. 2008 [16]), follicle-stimulating hormone (FSH) and luteinizing hormone (LH) produce biologically active recombinant FSH and LH by Drosophila S2 cells and have differential actions on reproductive biology (Aroua et al. 2012 [17]). Plasma progesterone and estradiol increase after heterologous gonadotropin (hCG) treatment (Colombo et al. 1987 [18]).

The effect of hormones on sex determination and growth by steroids [14], [19]-[21] was studied in detail.

In this mini-review, a model is presented suggesting that the relationship between the environment, hormones and sex determination affects growth. The relevance of such a model, not only in providing basic information, but also with respect to aquaculture, is described.

\subsection{Environmental Effect on Sex Differentiation and Growth of European Eel}

The European eel is a catadromous and carnivorous species having a complex lifecycle in sea and freshwater [10]. The European eel spawn in the Sargasso Sea in late winter and spring [1], [4]. The leaf-shaped larvae of European eel (leptocephali) [5] are brought to the continental shelf of Europe by the Gulf Stream.

Before the eel enter into the freshwater of rivers in Europe and Mediterranean countries, the larvae metamorphose to glass eels. During periods in freshwater, they undergo growth and maturation, and change their pigments to yellow eels and silvery eels. Sex differentiation in eels occurs during the yellow eel stage [18], [22] [23]. The eels become sexually mature at the silver eel stage. Young eels live in freshwater, where they stay for a period of 6 - 12 years for males and 9 - 18 years for females [1]. As silver eels become sexually mature, they swim back to the sea and spawning grounds in the Sargasso Sea [1]. Eel is an antic animal that lives in solitary in the ground [1]. Based on experimental growing of eel under artificial and aquacultural conditions, many data support the density effect on sex differentiation (Figure 1). European eels maintain high densities, with the percentage of males being significantly higher compared to females.

Under artificial conditions during growth, a very high variation in growth was found [2], and the important environmental factor affecting growth was density [10]. The rapid-growth eels become females and the slowgrowth eels become males [24]. The high density of growth significantly reduces growth, and estradiol increases

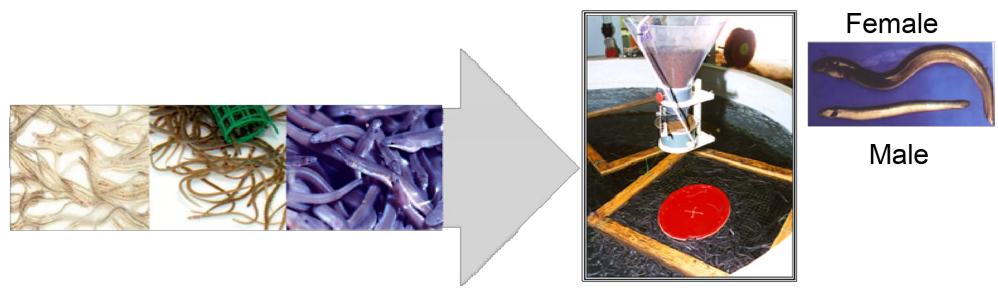

Figure 1. European eel grown under aquacultural conditions. 
growth and the percentage of females in the population [24]. The relationship between environment and sex differentiation among males and females is presented in Figure 2.

The proposed model described in Figure 1 might be explained by a study on hormone control reproduction and growth. In other words, the effect of the environment is on the hormonal axis.

\subsection{Hormonal Involvement in Sex Differentiation in Eel}

European eels belong to teleosts, as in other vertebrates, and growth and reproduction are tightly regulated, mainly via the hypothalamus-pituitary axis [25]. The hypothalamic decapeptide, gonadotropin-releasing hormone (GnRH), controls the release of pituitary gonadotropins, follicle-stimulating hormone (FSH) and luteinizing hormone (LH), which, in turn, control gametogenesis [26]. It is becoming increasingly evident that growth hormone (GH) plays a role in reproduction [25], [27]-[29]. A complex regulatory system involving multiple stimulatory and inhibitory factors may control the GH axis. In addition to its role in development and somatic growth, GH is involved in spermatogenesis regulation [11].

Previous studies support the hypothesis that sex hormones affect growth in European eel. Moreover, the administration of $17 \beta$-estradiol $\left(\mathrm{E}_{2}\right)$ in the diets affects growth more than $17 \alpha$-methyltestosterone (MT) [30]. A high percentage (70\%) of females was found among the European eels administered $E_{2}$ (60 mg/Kg diet) [20]. This result is supported by other studies [21], [31]. The hormone controlling the $E_{2}$ is FSH. Cloned [17] cDNA of European eel and the RNA level of FSH were significantly higher than in males [32]. Moreover, the expression of aromatase (EeCYP19) gene during the process of sex determination in adult male gonads was lower when compared to the adult female group [21], [31].

On the other hand, the transcription of GH is significantly higher in female eels than in males [11]. In the model for the environmental effect on sex differentiation and growth (Figure 2), it is proposed that low density in the hypothalamus-pituitary-gonad axis is affected by high FSH [32] and gonad synthesis $E_{2}$ by EeCYP19, and $\mathrm{E}_{2}$ affects gonad to ovary differentiation [21], [31].

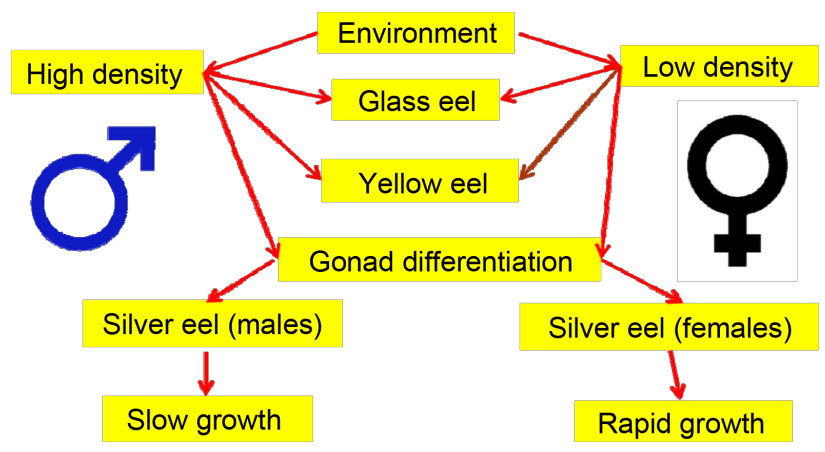

Figure 2. Proposed model of the effect of environment and density on sex differentiation [2], [10], [11], [14], [19]-[21].

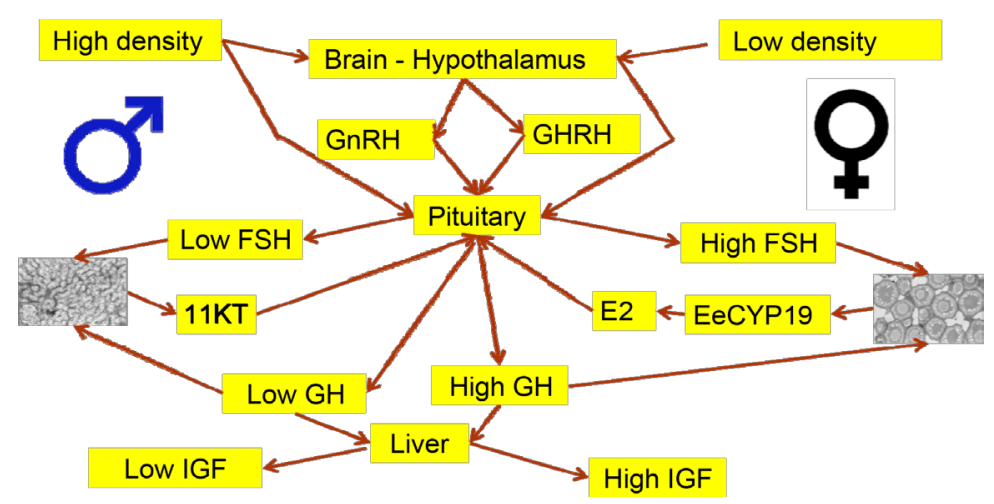

Figure 3. The relationship between environment and hormones involved in the differentiation of gonads in European eel [11], [13], [14], [17]-[21], [24]. 
$E_{2}$ affects the increase in growth compared to testosterone [29], and GH transcription in females was significantly higher than in males [11]. These results show the effect of $E_{2}$ on GH in the model (Figure 2). Growth hormone is affected both directly by growth and the insulin-like growth factor (IGF) system in the liver. The administration if insulin in the European eel diet significant increases growth rate [33]. In Japanese eel (Anguilla japonica), insulin-like growth factor-II (IGF-II) cDNAs were cloned and their mRNA expression was examined in several tissues. Two eel IGF-II cDNAs, eIGF-II-1 and eIGF-II-2, were cloned from the liver [34] [35].

Under high density conditions where European eel grow, the mRNA level of FSH was significantly lower in males [32], and the inhibition to EeCYP19 significantly reduced the level of $E_{2}$. Moreover, the expression of aromatase (EeCYP19) gene during the process of sex determination in adult male gonads was lower when compared to the adult female group [21], [31]. Gonads that do not undergo differentiation do not change into ovaries, secrete 11-KT and very low $\mathrm{E}_{2}$ levels have a lesser effect on growth than ovaries [29] Figure 3.

\section{References}

[1] Tesch, F. (1977) The Eel Biology and Management of Anguillid Eel. Chapman and Hall, London.

[2] Degani, G. and Levanon, D. (1983) The Influence of Low Density on Food Adaptation, Cannibalism, and Growth of eels [Anguilla anguilla (L.)]. The Israeli Journal of Aquaculture-Bamidgeh, 35, 53-60.

[3] Panfili', J. and Ximénès, M.-C. (1994) Sources of Variation in Growth of the European Eel (Anguilla anguilla) Estimated from Otoliths. Canadian Journal of Fisheries and Aquatic Sciences, 51, 506-515.

[4] Tesch, F.W. (1978) Telemetric Observations on the Spawning Migration of the Eel (Anguilla anguilla) West of the European Continental Shelf. Environmental Biology of Fishes, 3, 203-209. http://dx.doi.org/10.1007/BF00691944

[5] Tesch, F.W. (1980) Occurrence of Eel Anguilla anguilla Larvae West of the European Continental Shelf, 1971-1977. Environmental Biology of Fishes, 5, 185-190. http://dx.doi.org/10.1007/BF00005354

[6] Tesch, F.W. (1982) The Sargasso Sea Eel Expedition 1979. Helgoländer Meeresunsters, 35, 263-277. http://dx.doi.org/10.1007/bf02006135

[7] Tesch, F.W. (1989) Changes in Swimming Depth and Direction of Silver Eels (Anguilla anguilla L.) from the Continental Shelf to the Deep Sea. Aquatic Living Resources, 2, 9-20. http://dx.doi.org/10.1051/alr:1989002

[8] Tesch, F.W. (2003) The Eel. Blackwell Science, Oxford. http://dx.doi.org/10.1002/9780470995389

[9] Ginneken, V.V. (2005) The European Eel (Anguilla anguilla, Linnaeus), Its Lifecycle, Evolution and Reproduction. Fish Biology and Fisheries, 15, 367-398. http://dx.doi.org/10.1007/s11160-006-0005-8

[10] Degani, G. and Gallagher, M.L. (1995) Growth and Nutrition of Eels. Laser Pages Publishing, Israel.

[11] Degani, G., Tzchori, I., Yom-Din, S., Goldberg, D. and Jackson, K. (2003b) Growth Differences and Growth Hormone Expression in Male and Female European Eels [Anguilla anguilla (L.)]. General and Comparative Endocrinology, 134, 88-93. http://dx.doi.org/10.1016/S0016-6480(03)00238-7

[12] Degani, G. and Gallagher, M.L. (1986) The Influence of 3,3’,5 Triiodo-L Thyronine on Growth, Survival and Body Composition of Slow Growing Development Elvers (Anguilla anguilla (L.)). Comparative Biochemistry and Physiology, 84A, 7-11. http://dx.doi.org/10.1016/0300-9629(86)90034-4

[13] Degani, G. and Dosoretz, C. (1986) The Effect of 3,3',5-Triiodo-L-Thyronine and 17-Alpha-methyltestosterone on Growth and Body Composition of the Glass Stage of the Eel (Anguilla anguilla L.). Fish Physiology and Biochemistry, 1, 145-151. http://dx.doi.org/10.1007/BF02290255

[14] Degani, G. and Gallagher, M.L. (1985) Effects of Dietary 17-I-Methyltestosterone and Bovine Growth Hormone on Growth and Food Conversion of Slow and Normally Growing Amercanelvers (Anguilla rostrata). Canadian Journal of Fisheries and Aquatic Sciences, 42, 610-629.

[15] Montero, M., Yon, L., Rousseau, K., Arimura, A., Fournier, A., Dufour, S. and Vaudry, H. (1998) Distribution, Characterization, and Growth Hormone-Releasing Activity of Pituitary Adenylate Cyclase-Activating Polypeptide in the European Eel, Anguilla Anguilla. Endocrinology, 139, 4300-4310.

[16] Kazeto, Y., Kohara, M., Miura, T., Miura, C., Yamaguchi, S., Trant, J.M., Adachi, S. and Yamauchi. K. (2008) Japanese Eel Follicle-Stimulating Hormone (Fsh) and Luteinizing Hormone (Lh): Production of Biologically Active Recombinant Fsh and Lh by Drosophila S2 Cells and Their Differential Actions on the Reproductive Biology. Biology of Reproduction, 79, 938-946. http://dx.doi.org/10.1095/biolreprod.108.070052

[17] Aroua, S., Maugars, G., Jeng, S.R., Chang, C.F., Weltzien, F.A., Rousseau, K. and Dufour, S. (2012) Pituitary Gonadotropins FSH and LH Are Oppositely Regulated by the Activin/Follistatin System in a Basal Teleost, the Eel. General and Comparative Endocrinology, 175, 82-91. http://dx.doi.org/10.1016/j.ygcen.2011.10.002

[18] Colombo, G., Romeo, G.G., Giovannini, G., Pelizzola, D., Catozzi, L. and Piffanelli, A. (1987) Testis Cytological 
Structure, Plasma Sex Steroids, and Gonad Cytosol Free Steroid Receptors of Heterologous Gonadotropin (HCG)Stimulated Silver Eel, Anguilla anguilla L. General and Comparative Endocrinology, 65, 167-178. http://dx.doi.org/10.1016/0016-6480(87)90162-6

[19] Degani, G. (1985) The Influence of 17- $\alpha$-Methyltestosterone on Body Composition of Eels (Anguilla Anguilla (L.)). Aquaculture, 50, 23-30. http://dx.doi.org/10.1016/0044-8486(85)90149-8

[20] Degani, G. and Kushnirov, D. (1992) Effects of 17 $\beta$-Estradiol and Grouping on Gender Determination of European Eels. Progressive Fish-Culturist, 54, 88-91. http://dx.doi.org/10.1577/1548-8640(1992)054<0088:EOEAGO>2.3.CO;2

[21] Tzchori, I., Degani, G., Elisha, R., et al. (2004) The Influence of Phytoestrogens and Oestradiol-17 $\beta$ on Growth and Sex Determination in the European Eel (Anguilla anguilla). Aquaculture Research, 35, 1213-1219. http://dx.doi.org/10.1111/j.1365-2109.2004.01129.x

[22] Colombo, G. and Grandi, G. (1990) Gonad Sex Differentiation of Anguilla anguillaby Sex Steroid. International Reviews in Hydrobiology, 75, 763-773. http://dx.doi.org/10.1002/iroh.19900750610

[23] Geffroy, B. and Bardonnet, A. (2015) Sex Differentiation and Sex Determination in Eels: Consequences for Management. FISH and FISHERIES, 17, 375-398. http://dx.doi.org/10.1111/faf.12113

[24] Kushnirov, D. and Degani, G. (1991) Growth Performance of European Eel (Anguilla anguilla) under Controlled Photo Cycle and Shelter Availability. Aquaculture Engineering, 10, 219-226.

[25] Levy, G. and Degani, G. (2013) The Role of Brain Peptides in the Reproduction of Blue Gourami Males (Trichogastertrichopterus). Journal of Experimental Zoology Part A: Ecological Genetics and Physiology, 319, 461-470. http://dx.doi.org/10.1002/jez.1809

[26] Yaron, Z., Gur, G., Melamed, P., Rosenfeld, H., Elizur, A. and Levavi-Sivan, B. (2003) Regulation of Fish Gonadotropins. International Review of Cytology, 225, 131-185. http://dx.doi.org/10.1016/S0074-7696(05)25004-0

[27] Levy, G. and Degani, G. (2012) Involvement of GnRH, PACAP and PRP in the Reproduction of Blue Gourami Females (Trichogaster trichopterus). Journal of Molecular Neuroscience, 48, 603-616. http://dx.doi.org/10.1007/s12031-012-9730-8

[28] Levy, G. and Degani, G. (2011) Evidence of a Reproduction-Related Function for Pituitary Adenylate Cyclase-Activating Polypeptide-Related Peptide in an Anabantidae Fish. Journal of Molecular Endocrinology, 46, 101-110. http://dx.doi.org/10.1530/JME-10-0065

[29] Levy, G., Gothilf, Y. and Degani, G. (2009) Brain Gonadotropin Releasing Hormone3 Expression Variation during Oogenesis and Sexual Behavior and Its Effect on Pituitary Hormonal Expression in the Blue Gourami. Comparative Biochemistry and Physiology Part A: Molecular \& Integrative Physiology, 154, 241-248. http://dx.doi.org/10.1016/j.cbpa.2009.06.010

[30] Degani, G. (1986) Effect of Combined Dietary 17- $\beta$-Estradiol and 17- $\alpha$-Methyltestosterone on Growth and Body Composition of European Eels (Anguilla anguilla). Aquaculture, 59, 169-175. http://dx.doi.org/10.1016/0044-8486(86)90001-3

[31] Tzchori, I., Degani, G., Hurvitz, A. and Moav, B. (2004) Cloning and Developmental Expression of the Cytochrome P450 Aromatase Gene (CYP19) in the European Eel (Anguilla anguilla). General and Comparative Endocrinology, 138, 271-280. http://dx.doi.org/10.1016/j.ygcen.2004.06.007

[32] Degani, G., Jackson, K., Goldberg, D., Sarfati, R. and Avtalion, R.R. (2003) $\beta$ FSH, $\beta$ LH and Growth Hormone Gene Expression in Blue Gourami (Trichogaster trichopterus, Pallas 1770) during Spermatogenesis and Male Sexual Behavior. Zoological Science, 20, 737-743. http://dx.doi.org/10.2108/zsj.20.737

[33] Degani, G. and Abraham, M. (1992) Effect of Insulin in the Diet on the Growth of European Eels (Anguilla anguilla (L.). Fish Physiology and Biochemistry, 10, 223-227. http://dx.doi.org/10.1007/BF00004516

[34] Moriyama, S., Ayson, F.G. and Kawauchi, H. (2000) Growth Regulation by Insulin-Like Growth Factor-I in Fish. Bioscience, Biotechnology, and Biochemistry, 64, 1553-1562. http://dx.doi.org/10.1271/bbb.64.1553

[35] Moriyama, S., Yamaguchi, K., Takasawa, T., Chiba, H. and Kawauchi, H. ( 2008) Identification of Two Insulin-Like Growth Factor IIs in the Japanese Eel, Anguilla japonica: Cloning, Tissue Distribution, and Expression after Growth Hormone Treatment and Seawater Acclimation. Comparative Biochemistry \& Physiology Part B: Biochemistry \& Molecular Biology, 149, 47-57. http://dx.doi.org/10.1016/j.cbpb.2007.08.005 


\section{Submit or recommend next manuscript to SCIRP and we will provide best service for you:}

Accepting pre-submission inquiries through Email, Facebook, LinkedIn, Twitter, etc.

A wide selection of journals (inclusive of 9 subjects, more than 200 journals)

Providing 24-hour high-quality service

User-friendly online submission system

Fair and swift peer-review system

Efficient typesetting and proofreading procedure

Display of the result of downloads and visits, as well as the number of cited articles

Maximum dissemination of your research work

Submit your manuscript at: http://papersubmission.scirp.org/ 